YEARBOOK
of ANTITRUST
and REGULATORY
STUDIES
www.yars.wz.uw.edu.pl
Peer-reviewed scientific periodical, focusing on legal and economic issues of antitrust and regulation. Creative Commons Attribution-No Derivative Works 3.0 Poland License.

\section{$\overline{\mathrm{CAR}} \overline{\mathrm{S}}$}

Centre for Antitrust and Regulatory Studies, University of Warsaw, Faculty of Management www.cars.wZ.uw.edu.pl

\title{
Merger Control in Georgia - National Legislation and Case Law Review
}

\author{
by
}

Solomon Menabdishvili*

\section{CONTENTS}

I. General overview of merger rules

II. Concentrations examined by the Competition Agency of Georgia

III. Merger between LLC "Alta" and LLC "Eurotechnics Georgia"

IV. Acquisition of $100 \%$ of shares of "Nugeshi" Ltd by "Nikora Trade" Ltd

V. Conclusions

\section{Abstract}

Georgia has amended its Law on Competition in 2014 in order to fulfil its obligations set out by the Association Agreement with the European Union. Despite further approximations of its laws with those of the EU, some serious flaws remain. Merging parties are obliged to submit a prior notification to the Competition Agency of Georgia if their total turnover exceeds 20 million Georgian lari (GEL) or if the value of their assets exceeds 10 million GEL (7,692,307 EUR). One of the most interesting aspects of the Georgian merger control system rests in what the Competition Agency is authorised to do in case of a failure to fulfil the notification duty. This paper will discuss Georgian rules on concentrations as well as two of its recent merger cases.

* Lecturer at Tbilisi State University in Georgia; head of the Centre for Competition Law and Consumer Protection in Georgia; smenabdishvili@gmail.com. Article received: 15 July 2016; accepted: 26 September 2016.

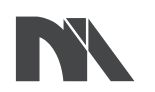

Ministry of Science and Higher Education

Republic of Poland
The creation of the English-language version of these publications is financed in the framework of contract No. 768/P-DUN/2016 by the Ministry of Science and Higher Education committed to activities aimed at the promotion of education. 


\section{Résumé}

La Géorgie a modifié sa loi sur la concurrence en 2014 afin de remplir ses obligations imposées par l'Accord d'association avec l'Union européenne. Malgré des rapprochements de la loi géorgienne avec la loi de l'Union européenne certains défauts persistent. Les parties de la concentration sont obligées de notifier l'Autorité de la concurrence géorgienne si leur chiffre d'affaires total dépasse 20 millions de lari géorgien (GEL) ou si la valeur de leurs actifs dépasse 10 millions de GEL (7.692.307 EUR). Lun des aspects les plus intéressants du système géorgien de contrôle des concentrations concerne les compétences de l'Autorité de la concurrence en cas de la violation de l'obligation de notification par l'entreprise. Cet article va analyser les règles de la loi géorgienne concernant les concentrations, ainsi que les deux affaires de concentration récentes.

Key words: competition; concentration.

JEL: K21

\section{General overview of merger rules}

The Parliament of Georgia has adopted a new Law on Competition in 2012 (hereinafter, LC). However, to meet the EU' criteria for signing the Free Trade Agreement, a further approximation of the LC with European competition rules was necessary. The new Georgian Government initiated in 2014 an amendment act, which was adopted on 27 March 2014. In light of these developments, all key domestic competition rules can now be found in the LC of Georgia. However, the LC contains a number of serious flaws which must be rectified as soon as possible. This review will discuss one of them namely Georgia's provisions on merger control.

According to paragraph 1 of Article 11 LC, a concentration includes:

a) merger of two or more independent undertakings resulting in the formation of a single undertaking;

b) gaining of direct or indirect control over an undertaking or its business share through the purchase of securities or interests, or through an agreement or otherwise, by a person already controlling at least one undertaking;

c) participation of one and the same person in the management boards of different undertakings;

d) the establishment of a joint venture, provided that it performs all the functions of an independent undertaking for a long period ${ }^{1}$.

${ }^{1}$ See Georgian Law on Competition at: http://competition.ge/en/page2.php? $p=4 \& m=62$ (15.07.2016). 
Paragraph 3 of Article 11 LC defines the term "control" as rights, agreements or other means that separately or together create the possibility to substantially influence an undertaking or its part, in particular:

a) ownership of an undertaking and/or the right to use its assets, fully or partially;

b) the right (including contractual rights) that gives substantial influence over the composition of the management boards, voting rights, and decisions of an undertakings ${ }^{2}$.

Therefore, the LC provides that any positive or negative control ${ }^{3}$ over a decision of an undertaking that has a substantial influence upon it can be regarded as concentration. According to the provision, any agreement or right that allows an undertaking to exercise control (positive, as well as negative control) over another undertaking's decisions is regarded as a concentration.

Paragraph 4 of Article 11 LC declares that a concentration is compatible with a normal competitive environment if it does not substantially distort effective competition in the goods or services market of Georgia, or of any significant part of Georgia, and if it does not result in the gaining or strengthening of a dominant position. On the other hand, according to paragraph 5 of Article $11 \mathrm{LC}$, a concentration is inadmissible if it substantially distorts effective competition in the goods or services market of Georgia, or any significant part of Georgia, and if it results in the gaining or strengthening of a dominant position.

The Chairman of the Competition Agency of Georgia has approved on 30 September 2014 Order \#30/09-4 on the Procedure on Submission and Consideration of Notification about Concentration ${ }^{4}$. Article 3 of the Order sets out the rules on pre-merger notifications. Advance notification of mergers to the Agency is compulsory when the merging parties meet one of the following criteria:

1) aggregate annual turnover of the merging parties on the territory of Georgia exceeds 20 million Georgian lari (hereinafter, GEL), and an annual turnover of at least two members of the concentration from each economic agent exceeds 5 million GEL (1.923,076 EUR);

2) joint value of the operating assets of the merging parties on the territory of Georgia exceeds 10 million GEL and the value of the operating assets

2 Ibidem.

3 So-called negative control exists where a shareholder is able to veto strategic decisions in an undertaking. See: Directorate for Financial and Enterprise Affairs, Competition Committee, Working Party No. 3 on Co-operation and Enforcement: Definition of Transaction for the Purpose of Merger Control Review, 18 June 2013, para. 2.2.2; retrieved from: http://ec.europa.eu/ competition/international/multilateral/2013_june_definition_transaction_en.pdf (25.09.2016).

${ }^{4}$ See the Procedure on Submission and Consideration of Notification about Concentration at: http://competition.ge/en/page2.php? $\mathrm{p}=4 \& \mathrm{~m}=141(15.07 .2016)$. 
on the territory of Georgia of at least two members of the concentration from each economic agent exceeds 4 million $\mathrm{GEL}^{5}$ (1,538,461 EUR).

According to Article 4 LC, when calculating the annual turnover of the merging parties, account should be taken of the income from the previous year received from the sales of goods and services excluding taxes. Article 4(3) LC defines the list of entities whose turnovers should be taken into account in the calculation of the turnover of the merging parties, that is:

- direct parties to the concentration;

- undertakings directly or indirectly controlled by the merging parties or directly or indirectly controlling the merging party;

- other undertakings controlled by the undertaking controlling one of the merging party;

- undertakings jointly controlled by the merging parties. ${ }^{6}$

After the submission of a notification, the Agency has one month to carry out an examination of the proposed operation and to adopt a decision either on the conformity of the proposed concentration with the competitive environment, or on its inadmissibility. Depending on the complexity of the case, this time limit may be extended no further than by an additional two weeks. An absence of a reply within the indicated time limit shall be deemed as a positive response.

\section{Concentrations examined by the Competition Agency of Georgia}

According to the Annual Report of the Competition Agency of Georgia ${ }^{7}$, the latter received three notifications and one application concerning concentrations in 2015:

1) a notification of the acquisition of the operational assets of "Tbilcement Group" Ltd by "Heidelberg Georgia" Ltd;

2) a notification of the acquisition of $95 \%$ of the assets of "Deka" Ltd by "Medical Corporation Evex" JSC;

3) a notification of the acquisition of $50 \%$ of the assets of "GN- KO" Ltd by "Medical Corporation Evex" Jsc;

4) an application made by the N(N)LE "Center for Competition Law and Consumer Protection" concerning the acquisition of $100 \%$ of the

5 Ibidem.

6 Ibidem.

7 See the Report, p. 26, http://competition.ge/images/upload/Annual\%20Report-2015.pdf (15.07.2016).

8 Non-entrepreneurial (non-commercial) legal entity. 
shares of "Nugeshi" Ltd by "Nikora Trade" Ltd and it's compliance with competition legislation.

Two further merger notifications were submitted before 1 June 2016 according to the website of the Competition Agency of Georgia:

1) the notification of the merger of LLC "Alta" and LLC "Eurotechnics Georgia";

2) the notification of the acquisition of a $100 \%$ equity stake in JSC GPC ("GPC") by JSC "Georgia Healthcare Group"; GPC is one of the top three pharmaceutical wholesalers and retailers in Georgia; according to the information provided by the acquirer's own website, the GPC pharmacy chain has a $15 \%$ market share by sales, with 96 pharmacies across Georgia ${ }^{9}$.

This paper will focus on two of the abovementioned cases - the notification of the merger between LLC "Alta" and LLC "Eurotechnics Georgia" and the application concerning the acquisition of "Nugeshi" Ltd by "Nikora Trade" Ltd.

\section{Merger between LLC "Alta" and LLC "Eurotechnics Georgia"}

LLC "Alta" and LLC "Eurotechnics" decided to merge into a single company. Before the operation, both companies were known to be selling electric goods, albeit differentiated ones. The Competition Agency in its decision ${ }^{10}$ divided the products being sold by the two parties into two categories: "white" and "black" electric goods. The list of "black" electric goods comprised computers and mobiles; the "white" list it included household appliances.

According to the Agency, the product market comprised three markets:

1) black electric goods;

2) white electric goods and

3 ) installation services for electric goods ${ }^{11}$.

176 importers and only two local producers of electric goods were said to have been active in Georgia at the time of the merger.

The parties stated in the notification that they planned to unite their marketing and trademarks, introduce a full assortment of electric goods, carry

${ }^{9}$ See https://evex.ge/en/media-center/news/georgia-healthcare-group-plc-ghg-announcesthe-acquisition-of-gpc-one-of-the-largest-retail-and-wholesale-pharmacy-chains-in-georgia.page (15.07.2016).

10 Order \#32 of 7 March 2016 - the order is not officially published on the Agency's website but it is provided upon request.

11 The Decision of the Agency, p. 8. 
out joint advertising campaigns, optimize costs and etc. They also intended to open stores in those Georgian cities where they were not yet present ${ }^{12}$.

According to the information provided by the parties, both had narrow sales profiles - LLC "Alta" sold mainly "black electric goods" (such as computers, mobile phones, etc.) while LLC "Eurotechnics" offered mainly household appliances (such as freezers, washing machines, gas-stove, etc) ${ }^{13}$.

The parties argued that the intended merger complied with the competitive environment and would not generate a negative effect on the market for the following reasons:

1) the Georgian electric goods market was not very concentrated;

2) the merger would develop the market and result in an enhancement of competition by offering a wider selection of products to consumers;

3 ) concentration would result in the optimization of costs;

4) merging parties are active in different segments of electric goods and so the merger would not appreciably increase the market concentration level;

5) opening of new stores in different regions of Georgia would promote local employment;

6) the merging parties believed themselves to be in competition not only with local retail stores but also with other countries' producers, a fact that ruled out a restriction of competition in any form;

7) according to the data presented by the parties on the participation of their shareholders in other companies, it was clear that they did not participate in competing companies (there were not inter-dependent economic agents) and their influence on such companies' decisions was not material (because their participation did not exceed $20 \%$ of their shares $\left.{ }^{14}\right) .{ }^{15}$

According to the information provided in the decision of the Agency, LLC "Alta" would hold $60 \%$ of the shares in the new company while the remaining $40 \%$ would go to LLC "Eurotechniques Georgia". The parties were planning to decrease, or completely stop retail sales - their activities would mainly relate to the import and wholesale trade of electric goods ${ }^{16}$.

During its investigation, the Agency conducted a survey with the competitors of the merging parties. It sent out questionnaires to around 176 undertakings, although only around 43 responded. Only $74 \%$ of them answered the question regarding which economic agents did they consider as direct competitors?

\footnotetext{
12 Ibidem, p. 7.

13 Ibidem, p. 8-9.

14 Ibidem, p. 11.

15 Ibidem, p. 9-10.

16 Ibidem, p. 12.
} 
Only 30 of the surveyed companies saw LLC "Alta" and LLC "Eurtechniques Georgia" as each others' competitors, although the majority of them (58\%) did not see them as each others' direct competitors.

It is interesting to note the answers regarding the presumable effects of the intended merger. Only 29 of the surveyed undertakings submitted their views on this question. Most of them stated that the merger would have no effect on existing market competition. They noted that the merger may enhance competition in the long run. One of the respondents stated that mergers of large companies have taken place worldwide and introduced goods with unified trademarks. This practice leads, on the one hand, to a price reduction and, on the other, intense competition that aims to improve product quality. Yet some of the competitors were of the opinion that the merger could have a negative impact on competition. They stated that after the concentration the parties would have market power, the number of market players would shrink and the competitive environment would diminish. According to the data provided by the Agency, $38 \%$ of the surveyed companies thought that the intended operation would not impact existing competition, $17.2 \%$ thought that the merger would have a pro-competitive effect, and only $10.3 \%$ had a negative attitude towards the merger ${ }^{17}$.

The Agency mentioned in its decision the European Commission's opinion on electric goods, saying that the EU authority considers that the market of electric goods is a single integral market, and that it is not advisable to divide it into categories ${ }^{18}$. Nevertheless, the Georgian Competition Agency divided the domestic market into "black" and "white" electric equipment ${ }^{19}$. In fact, the Agency included also in the relevant product market installation services for electric goods ${ }^{20}$.

In the opinion of the Agency, the relevant geographic market coves the whole territory of Georgia while product sales were not characterized by seasonal trends ${ }^{21}$. In its decision, the authority discussed issues relating to barriers to entry, expansion and exit.

According to the information gathered by the Agency, LLC "Alta" was the leading importer of "black electric goods" in 2014, enjoying the same position in 2015. Although the Agency said that the merging parties were selling different categories of electric goods, the decision stated that LLC "Eurotechnics

17 The Decision of the Agency, p. 24.

18 EC Decision, Case No. COMP/M.4226 DSGI/FOTOVISTA, http://ec.europa.eu/ competition/mergers/cases/decisions/m4226_20060629_20310_en.pdf (15.07.2016).

19 The Decision of the Agency, p. 26.

${ }^{20}$ Ibidem.

21 Ibidem, p. 27. 
Georgia" sold "black electric goods" in 2014-201522 as well. Still, the decision did not specify the amount of "black electric goods" the latter managed to sell, or what its market position was in terms of percentages. According to diagram \#10 reflecting the sales of black electric goods in 2014-2015 provided in the decision of the Georgian Competition Agency, LLC "Alta" held the $1^{\text {st }}$ position while LLC "Eurotechnics Georgia" was in the $3^{\text {rd }}$ position in that time frame ${ }^{23}$.

The Agency used the HHI index and arrived at an overall HHI reaching 426,875 . The merging parties' common share in the total HHI was 14,924 with a delta of 104,314 after the concentration ${ }^{24}$.

There were around 466-462 importers of "white electric goods" in Georgia in 2014-2015. The HHI was correspondingly 675,048 and 666,175 , the merging parties' common share in the total HHI was 8,864 with a delta of 18,068 after the merger. Diagram \#11 provided in the Agency's decision shows that LLC "Eurotechnics Georgia" was in the $2^{\text {nd }}$ position in 2014 and $3^{\text {rd }}$ position in $2015^{25}$ in the import market of the goods. As for the sales of white electric goods, diagram \#13 shows that LLC "Eurotechnics Georgia" was in the leading position in 2014 and moved to the $2^{\text {nd }}$ position in 2015. LLC "Alta" had a small market share in the market for selling white electric goods in $2015^{26}$.

Another relevant product market delineated in this case related to installation services for electric goods. The HHI for this market reached 8599,84 in 2014 showing that the market was highly concentrated. Although the HHI dropped to 7245,504 in 2015, this figure marked it as highly concentrated. After the merger, the parties' share in the total HHI would be $94.63 \%$, the HHI index would be 8996,910 with a delta of 1721,407 . According to diagram \#14, LLC "Alta" had a leading position in the installation services' market, followed by LLC "Eurotechnics Georgia"27.

In summary, although the markets for both black and white electric goods were characterised by low concentration levels, the installation services' market was already highly concentrated even before the merger. Yet the Agency cleared the merger unconditionally, merely obliging the parties to submit to the authority a yearly report on new deals having the ability to significantly restrict competition. Importantly however, the Agency is not entitled to abolish an already implemented concentration ex post, provided it had cleared the operation according to applicable competition rules. There is

\footnotetext{
22 Ibidem, p. 31-32

23 Ibidem, p. 33.

24 Ibidem, p. 32.

25 Ibidem, p. 34-35.

26 Ibidem, p. 36.

27 Ibidem, p. 37.
} 
no legal instrument to control already implemented mergers ex post whether they had been cleared by the Agency earlier or not.

There is a number of requirements in EU competition law for a merger to be cleared. For instance, one of the criteria is the efficiency that can be achieved by the intended merger. In the view of the European Commission (hereinafter, EC), efficiencies resulting from a merger might outweigh its negative effects on competition and, in particular, the potential harm to consumers that it might otherwise have ${ }^{28}$. In order to declare a merger compatible with the common market, the EC requires sufficient evidence proving that the efficiencies generated by the merger are likely to enhance the ability and the incentive of the merged entity to act pro-competitively to the benefit of consumers, thereby counteracting the adverse effects on competition which the merger might otherwise have ${ }^{29}$.

When the EC takes account of the efficiencies stemming from a planned merger, it pays attention to the following factors:

- first, the efficiencies must benefit consumers;

- second, the efficiencies must be merger-specific;

- third, the efficiencies must be verifiable ${ }^{30}$.

Other types of efficiencies might be found in new or improved products or services.

It is important to note that claimed efficiencies have to be substantial, timely, likely to be realized and to be passed on to a sufficient degree to consumers $^{31}$.

In the EC's view, mergers may generate various types of efficiency gains that can lead to lower prices or other benefits to consumers. One of them might be cost savings in production or distribution, which incentivises merging parties to cut prices. The EC argues that cost efficiencies that generate reductions in variable or marginal costs are more likely to be relevant to the assessment of efficiencies than reductions in fixed costs ${ }^{32}$.

In the context of merger specificity, the EC argues that efficiencies claimed by the parties must be a direct consequence of the merger and cannot be achieved to a similar extent by less anti-competitive and realistic alternatives. It is up to the merging parties to demonstrate that there are no less restrictive, realistic and attainable alternatives of a non-concentrative nature, or of

${ }^{28}$ Guidelines on the Assessment of horizontal mergers under the Council Regulation on the Control of the concentrations between undertakings, para. 76, http://eur-lex.europa.eu/ legal-content/EN/TXT/?uri=celex:52004XC0205(02) (15.07.2016).

${ }^{29}$ Ibidem, para. 77.

30 Ibidem, para. 78.

31 Ibidem, para. 83-84.

32 Ibidem, para. 80. 
a concentrative nature than the notified merger which preserve the claimed efficiencies $^{33}$.

As for the verifiability, the EC has to be reasonably certain that the claimed "efficiencies are likely to materialize and be substantial enough to counteract a merger's potential harm to consumers" 34 .

In the decision of the Agency on the intended merger of LLC "Alta" with LLC "Eurotechnics Georgia", the authority only mentioned the efficiencies claimed by the merging parties. However, it did not examine whether they were merger-specific and verifiable. The decision does not state what type of costs savings would be generated or whether the efficiencies would be substantial, timely, likely to be realized and passed on to consumer to a sufficient degree. The merging parties held leading positions in different types of electric goods and could individually generate some of the claimed efficiencies, for instance, open stores in new cities, offer consumers a variety of electric goods, increase local employment, etc. Besides, it should be noted that the Agency thought that interdependence cannot be generated if a company holds a $20 \%$ share in a competing firm ${ }^{35}$. In practice, even a holder of a $5 \%$ share may substantially influence the decisions of an undertaking if the holder has special rights, for instance, the right to appoint a director or veto the decisions of the directors. Another important factor that the Agency failed to pay enough attention to is that the majority of competitors stated that the intended merger would be pro-competitive. In practice, competitors tend to express a positive attitude towards mergers with anti-competitive effects when they know that they can gain from it. For instance, in the case of a merger generating anti-competitive unilateral effects, a $3^{\text {rd }}$ party can benefit from both a higher price and higher volumes (Majumdar, 2015-2016, p. 13). Besides, mergers in the EU are usually examined by competition authorities with respect to different types of harms they can generate, such as unilateral effects or coordinated effects. In addition, there are so-called gap cases, which at first glance seem pro-competitive but in fact also require an in depth examination. It is thus fair to say that the Competition Agency of Georgia has failed to conduct a substantive analysis of the proposed merger.

Despite the incomplete examination and incorrect assessment of the risks stemming from this merger, the Agency declared this operation compatible with the normal competitive environment.

\footnotetext{
33 Ibidem, para. 85.

${ }^{34}$ Ibidem, para. 86.

35 The Decision of the Agency, p. 11.
} 


\section{Acquisition of $100 \%$ of shares of "Nugeshi" Ltd by "Nikora Trade" Ltd}

This operation concerned two large supermarket chains active in Georgia. Before the merger, "Nikora Trade" Ltd had 120 stores while "Nugeshi" Ltd had 25 stores and 63 stalls (booths) ${ }^{36}$ - they were each other's direct competitors selling groceries.

It is clear from the LC of Georgia that merging parties are obliged to submit a prior notification on an intended merger to the Competition Agency if they fulfil the notification requirements specified in Article 3 of the Order \#30/09-4 on the Procedure of Submission and Consideration of Notification about Concentration ${ }^{37}$. The authority carries out a competitive assessment of the notified merger on the basis of Article $11 \mathrm{LC}^{1}$, prepares its conclusions and issues its opinion. A negative opinion of the Agency on the intended merger shall be taken into account by the National Agency of the Public Registry upon the registration of the concentration. The notification duty placed on the merging parties is not dependent on the market shares of the merging parties but on their annual turnover or the value of their assets.

Specifically with regard to this concentration, the aforementioned parties failed to notify the intended merger in advance to the Agency. As a result, the Public Registry registered the operation without a pre-emptive opinion of the Agency.

The N(N)LE the "Center for Competition Law and Consumer Protection" (for more information on the Center see: Menabdishvili, 2016, p. 246-247) lodged an application to the Agency to review the legality of the acquisition of $100 \%$ of the shares of "Nugeshi" Ltd by "Nikora Trade" Ltd on 31 December 2015. The Agency started administrative proceedings on the basis of this application and held consultative meetings with the merging parties.

The Agency issued on 26 February of 2015 Order \#27 on the said concentration and concluded that the parties had in fact been obliged to notify the merger before its implementation. The Agency argued that all formal requirements had been fulfilled - that is, individual and aggregate annual turnover of the merging parties within the territory of Georgia before the merger had exceeded the limit established by Georgia's existing

\footnotetext{
36 Small shops that are placed on the street, example can be found via the following link: http://www.panoramio.com/photo/86327802 (15.07.2016).

37 See the Procedure on Submission and Consideration of Notification about Concentration at: http://competition.ge/en/page2.php? $\mathrm{p}=4 \& \mathrm{~m}=141(15.07 .2016)$.
} 
competition rules. The undertakings involved in the concentration had thus been obliged to get the Agency's prior approval of the concentration before its registration. "Nikora Trade" Ltd contended that the acquisition of shares cannot be qualified as a concentration within the meaning of Article 11(1(b)) LC because it did not control any additional companies before the operation. By contrast, the Agency found that the company already controlled an additional undertaking - "Lazi Holding" Ltd - within the meaning of Article 11(1(b)) LC. In fact, "Nikora Trade" Ltd owned 67\% of the shares of "Lazi Holding" Ltd, which enabled the owner, in the opinion of the Agency, to exercise direct control over "Lazi Holding" Ltd. The Agency concluded therefore that:

1) the acquisition of the shares is a concentration within the meaning of Article 11(1(b)) LC and the parties infringed Articles 11 and $11^{1} \mathrm{LC}$;

2) the parties to the concentration were under the obligation to notify in advance the intended merger to the Agency, which they failed to do.

An interesting point to stress in the context of this concentration is that even though the notification duty was breached, the Agency has no authority to impose any type of fines on the infringing parties. Neither does it have the power to abolish the transaction ex post, unlike in the EU where it is an offence to consummate a merger without a prior clearance from the EC (Whish and Bailey, 2012, p. 829). The EC, on the basis of Article 14 of the Council Regulation No. 139/2004 on the control of concentrations between undertakings ${ }^{38}$, has in such cases the right to impose fines not exceeding $10 \%$ of the aggregated turnover of the undertaking that had failed to notify a concentration prior to its implementation.

Article 33 LC provides sanctions that can be imposed by the Agency on economic agents. The fine cannot exceed $5 \%$ of the turnover achieved in the preceding business year by the undertaking concerned. In the case of a failure to eliminate the legal basis of a violation or a repeated violation, the Agency is entitled to impose a fine in the amount not exceeding $10 \%$ of the annual turnover for the previous financial year ${ }^{39}$. The serious flaw of this Article lies in the fact that the Agency is only entitled to impose fines on undertakings breaching Article 6 LC (abuse of dominance) or Article 7 LC (cartel). Therefore, if parties of a concentration fail to prenotify their intended operation, the Agency is at the moment not entitled to fine them at all. On the one hand therefore, the LC of Georgia has

38 Council Regulation (EC) No 139/2004 of 20 January 2004 on the control of concentrations between undertakings (the EC Merger Regulation), OJ L 24, 29.01.2004, p. 1.

39 See the Law on Competition of Georgia at http://competition.ge/en/page2.php? $\mathrm{m}=62$ (15.07.2016). 
imposed a pre-emptive merger notification duty but on the other, it has failed to enshrine any type of penalties on undertakings breaching this obligation.

\section{Conclusions}

One of the main goals of the Law on Competition of Georgia is to prevent unlawful competition restrictions between economic agents ${ }^{40}$. The Competition Agency of Georgia should therefore be in charge of monitoring the activities of its economic agents. In discharging its mission, the Agency has the right to:

- monitor markets;

- start an investigation on its own initiative and as a result of an application or complaint if a reasonable suspicion exists of an infringement of competition rules; and

- impose fines on undertakings according to Article $33 \mathrm{LC}$ if they infringed Article 6 LC (abuse of dominance) or Article 7 (cartels) LC.

However, the LC of Georgia provides for financial penalties only in cases of breaches of Articles 6 and 7 LC - existing legislation does not provide for fines for merging parties subject to the notification duty when they fail to pre-notify their intended concentration. Moreover, the competition authority is not entitled to annul such transaction ex post. Unfortunately, the Agency has not tried to apply other competition rules to concentrations that had not been pre-notified, particularly Article 6 or Article 7 LC, along the same lines as it was the case in the EU before the merger regulation came into force.

The above case law and legislation review shows that the Competition Agency of Georgia does not have at its disposal the appropriate instruments that are necessary to ensure the effective control of concentrations. This is so despite the fact that according to Article 204 of the Association Agreement, Georgia is obliged to have comprehensive competition rules providing effective concentration control to avoid significant impediment to effective competition. Besides, it is important to note that Georgia has the duty to maintain an authority responsible and appropriately equipped for the effective enforcement of competition rules.

So called "gun-jumping" (Whish and Bailey, 2012, p. 858) is thus not penalized by the Law on Competition of Georgia. This situation must be seen as a very serious flaw of Georgia's existing legislation because without

40 Ibidem, Article 2. 
the imposition of penalties on undertakings failing to fulfil a mandatory prenotification duty, effective merger control cannot be maintained. Furthermore, cartel members can easily evade antitrust responsibility that arises under anticartel provisions if they are able to easily merge if the latter are not subject to any public control. Importantly also, without effective merger control, it is impossible to regulate changes in market structure, which may in turn raise serious competition concerns.

\section{Literature}

Majumdar, A. (2015-2016). Economics for Competition Law. London: King's College.

Menabdishvili, S. (2016), Center for Competition Law and Consumer Protection, Tbilisi (Georgia), Yearbook of Antitrust and Regulatory Studies 9(13), 246-247.

Whish, R. and Bailey, D. (2012). Competition Law. Oxford: Oxford University Press. 